\title{
IDENTIFICATION OF HAEM-PROTEINS IN THYLAKOID POLYPEPTIDE PATTERNS OF BARLEY
}

\author{
by
}

GUNILLA HØYER-HANSEN

\author{
Department of Physiology, Carlsberg Laboratory, \\ Gamle Carlsberg Vej 10, DK-2500 Copenhagen Valby
}

\begin{abstract}
Keywords: Haem, haem associated peroxidase activity, SDS-polyacrylamide gel electrophoresis, LiDS-polyacrylamide gel electrophoresis, cytochromes
\end{abstract}

Thylakoid polypeptides from barley were separated by polyacrylamide gel electrophoresis by use of either SDS or LiDS as the detergent. Staining of either gel-type with 3,3,5,5'tetramethylbenzidine- $\mathrm{H}_{2} \mathrm{O}_{2}$ revealed two barley polypeptides with peroxidase activity. The same two polypeptides were shown to incorporate $\left[{ }^{4} \mathrm{C}\right]-\delta$ aminolaevulinic acid, identifying haem as their prosthetic group. The haem-protein with a molecular weight of 33,000 is cytochrome $f$ and that with a molecular weight of 20,000 is suggested to be a subunit of cytochrome $b_{6}$. The two polypeptides are also present in etioplast membranes, which from prior spectroscopic evidence are known to contain cytochromes $f$ and $b_{6}$.

\section{INTRODUCTION}

Several barley thylakoid polypeptides have been identified and characterized functionally with the aid of mutants and specific isolation procedures $(17,18,19,21,25,33)$. Photosynthetic defects in mutants correlate with the absence or reduction of certain polypeptides in electrophoretograms of thylakoids. For example, the barley mutant viridis $-c^{12}$ lacks chlorophyll $a$ - protein $3(17,19)$ and is deficient in photosystem II. Similarily, mutants in Chlamydomonas lacking polypeptide 6 are considered to be defective in the reaction center of photosystem II (5). Antibodies raised to the Chlamydomonas polypeptide were shown by crossed immunoelectrophoresis to produce a precipitation peak with both the barley and the Chlamydomonas polypeptide. This strongly implies chlorophyll $a$ -

\footnotetext{
Abbreviations: $\mathrm{Chl} a$-AP3 = chlorophyll $a$-apoprotein 3 (19); Chl ${ }_{a}$-Pl $=$ chlorophyll $a$-protein 1 (19); $\mathrm{Chl} a / b$-P2 $=$ chlorophyll $a / b$-protein $2(19)$; DTT $=$ dithiothreitol; HP $=$ high potential; LiDS $=$ lithium dodecyl sulfate; $\mathrm{LP}=$ low potential; $\mathrm{PAGE}=$ polyacrylamide gel electrophoresis; $\mathrm{PPO}=2,5$-diphenyloxazole; SDS = sodium dodecyl sulfate; TMBZ $=3,3^{\prime}, 5,5^{\prime}$-tetramethylbenzidine.
} 
G. HøYER-HANSEN: Barley thylakoid haem-proteins
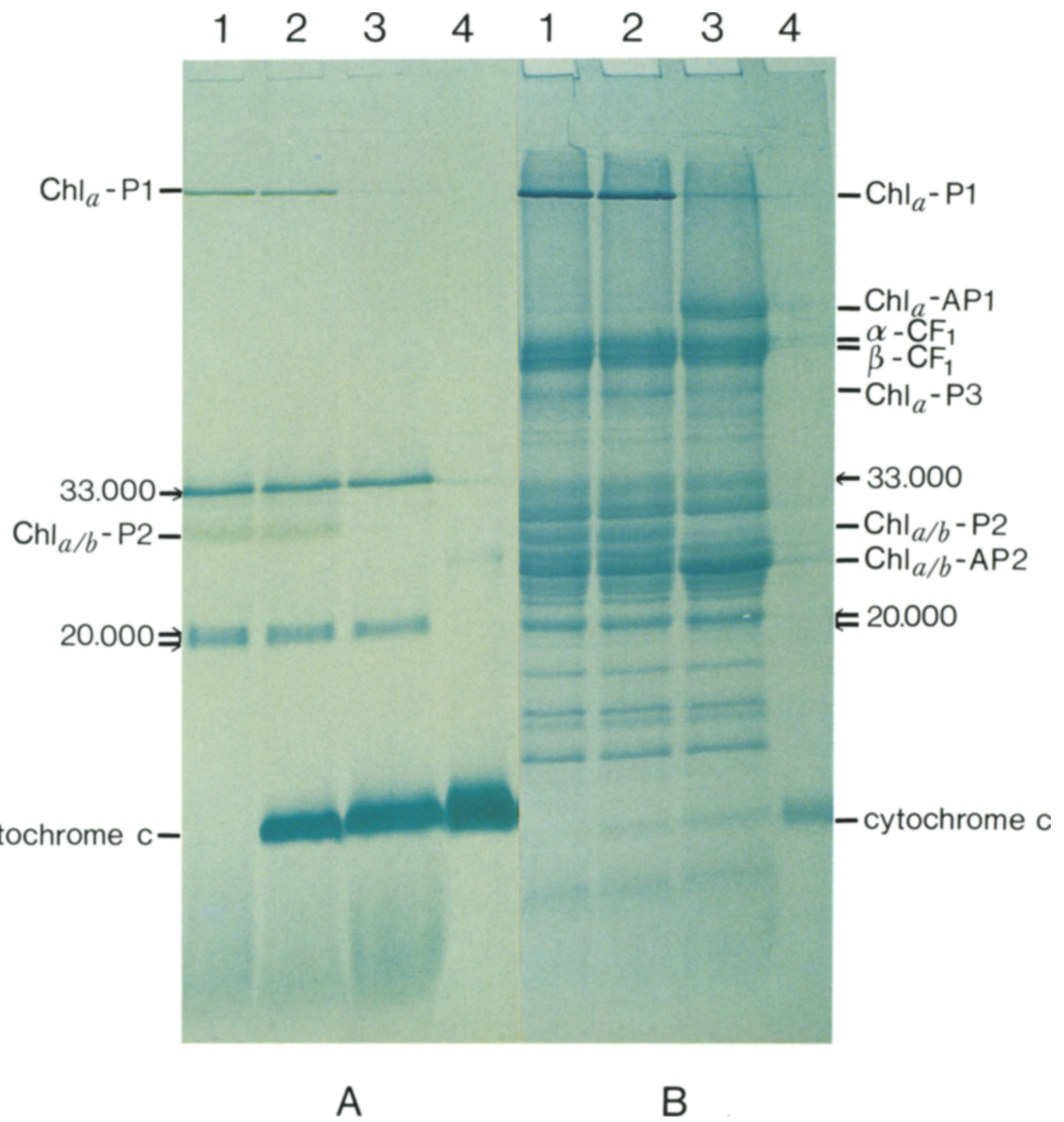

Figure 1. Barley thylakoid polypeptides separated by Li-dodecyl sulfate polyacrylamide gel electrophoresis and stained in A for haem associated peroxidase activity and restained in B for protein with Coomassie Blue.

Lane 1: Barley thylakoid polypeptides

2: Barley thylakoid polypeptides + cytochrome $\mathrm{c}$

3: As 2 but chlorophyll removed by heating to $100^{\circ} \mathrm{C}$ for $2 \mathrm{~min}$

4: $10 \mu \mathrm{g}$ cytochrome $\mathrm{c}$ 
G. HøyER-HANSEN: Barley thylakoid haem-proteins

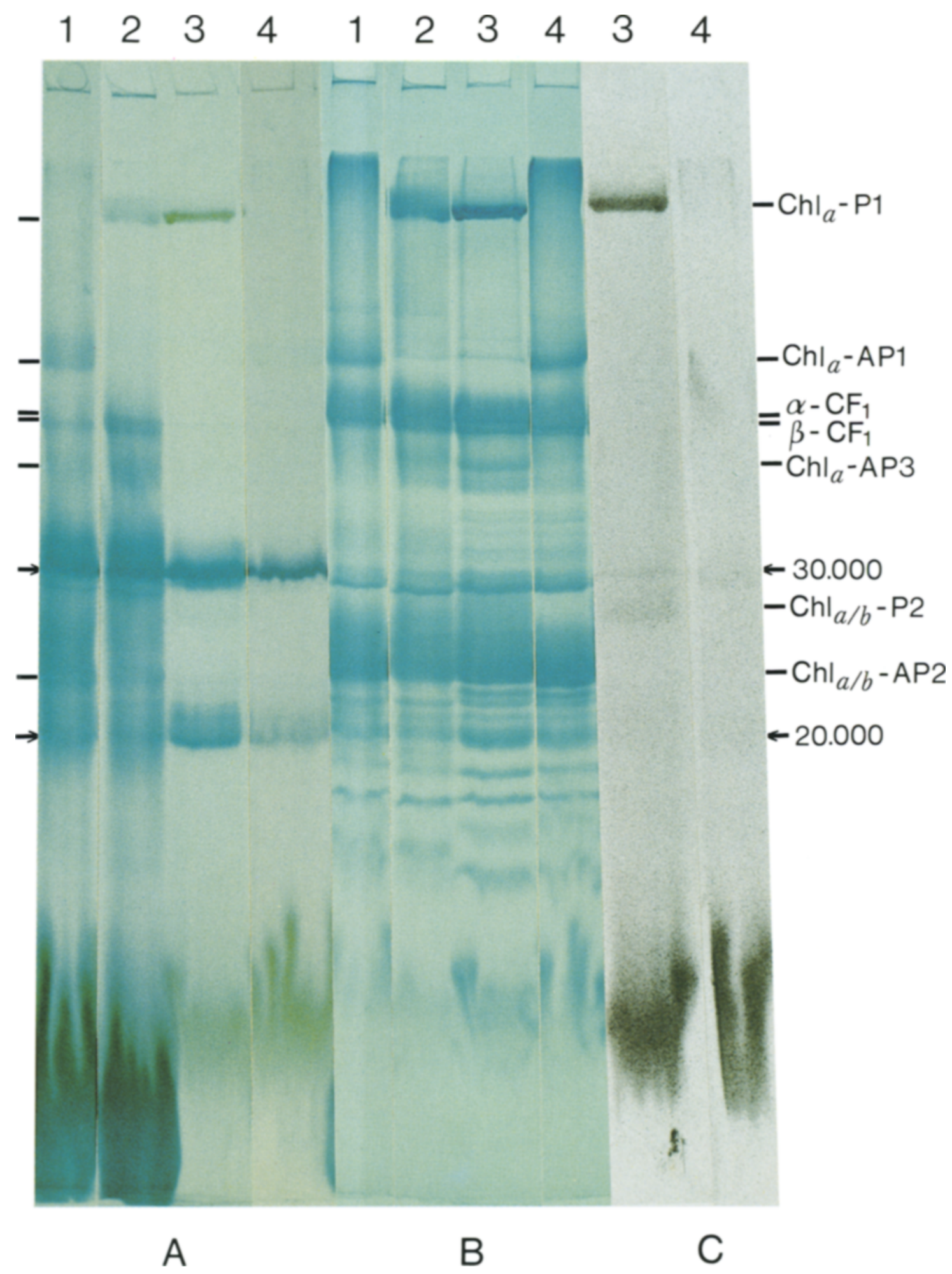


Figure 2. Non-specific binding of haem to thylakoid polypeptides and $\left[{ }^{4} \mathrm{C}\right]-\delta$-aminolevulinate incorporation into haem- and chlorophyll-proteins.

The thylakoid polypeptides were separated by sodium dodecyl sulfate polyacrylamide gel electrophoresis and stained in A for haem associated peroxidase activity and in B with Coomassie Blue. C are autoradiograms.

Lane 1: Barley thylakoid polypeptides +100 pmoles of hemin.

Chlorophyll removed by heating to $100^{\circ} \mathrm{C}$ for $2 \mathrm{~min}$.

2: Barley thylakoids +100 pmoles of hemin

3: Barley thylakoid polypeptides labelled with $\left[{ }^{14} \mathrm{C}\right]-\delta$-aminolevulinate

4: As 3 but chlorophyll removed by heating to $100^{\circ} \mathrm{C}$ for $2 \mathrm{~min}$.

protein 3 as the most likely candidate for the photosystem II reaction center (24).

Other thylakoid proteins can be isolated with retained catalytic activity. This is the case with the extrinsic part of coupling factor $\mathrm{CF}_{1}$, which was recently characterized from barley (15). Antibodies raised to the native protein permitted the identification of all five subunits in the total barley thylakoid polypeptide pattern by crossed immunoelectrophoresis.

The presence of enzymatic activity in a protein band on a polyacrylamide gel can frequently be established by use of a suitable colour reaction when non-denaturing polyacrylamide gel electrophoresis systems are used (8). This is generally precluded in the denaturing gel systems necessary for separation of thylakoid membrane polypeptides. However, reactions which are catalyzed by prostethic groups remaining attached to the polypeptides during SDS-polyacrylamide gel electrophoresis are possible. An example of such a reaction is the peroxidase activity of haem in haem-proteins. This activity can be visualized by a colour reaction using 3,3',5,5'-tetramethylbenzidine (TMBZ) $-\mathrm{H}_{2} \mathrm{O}_{2}$ (32). The $\mathrm{Fe}^{3+}$ in haem is oxidized by $\mathrm{H}_{2} \mathrm{O}_{2}$ to $\mathrm{Fe}^{4+}$ which is then reduced by tetramethylbenzidine, resulting in a blue coloured product from tetramethylbenzidine. This staining procedure has been successfully applied for the detection of microsomal cytochrome $P-450$ and hemoglobin (32).

In this study it was investigated whether this procedure could be used to detect cytochromes in SDS- and LiDS electrophoretograms of barley thylakoids. Two bands were found to have peroxidase activity and incorporation of $\left[{ }^{14} \mathrm{C}\right]-\delta$ - aminolevulinic acid into these same bands was used to demonstrate that the peroxidase activity is due to haem.

\section{MATERIALS AND METHODS}

\subsection{Plant material}

Seeds of wild-type barley (Hordeum vulgare cv. Svalöfs Bonus) were germinated in tap water moistened vermiculite. The seedlings were grown at $20^{\circ} \mathrm{C}$ for 7 days either in continuous white light (1700 lux) or in the dark.

\subsection{Isolation of thylakoids and electrophoresis}

Thylakoids were isolated according to HøyerHANSEN and SimpSON (14) and if not used immediately they were frozen in small aliquots containing $0.1 \mathrm{M}-\mathrm{Na}_{2} \mathrm{CO}_{3}, 0.1 \mathrm{~m}-\mathrm{DTT}$. Electrophoresis was performed essentially according to the procedures published in $(5,7)$. Electrophoresis with LiDS as the detergent was carried out in 12-18\% polyacrylamide gradient gels run at $4^{\circ} \mathrm{C}$. Under these conditions some chlorophyll remained attached to $\mathrm{Chl}{ }_{a}-\mathrm{Pl}$ and $\mathrm{Chl}{ }_{a / b}-\mathrm{P} 2$, and with decreasing amounts of LiDS added to the sample to other chlorophyll-proteins. SDSPAGE was conducted with 11-15\% gradient gels run at room temperature. Under these conditions only $\mathrm{Chl}{ }_{a}-\mathrm{Pl}$ and to a lesser extent $\mathrm{Ch}{ }_{a} / b-\mathrm{P} 2$ retain chlorophyll. The buffers used in both LiDS- and SDS-PAGE were those described in (5). 


\subsection{Staining for haem associated peroxidase activity}

The procedure of Thomas, Ryan and Levin was used (32). Immediately after electrophoresis was completed, the gels were immersed in a solution composed of 3 parts of $6.3 \mathrm{~mm}-\mathrm{TMBZ}$ (Sigma Chem. Co.) in methanol and 7 parts of $0.25 \mathrm{M}-\mathrm{Na}$-acetate, $\mathrm{pH} 5.0$, and kept in the dark at room temperature with gentle shaking for 2 hours. Hydrogen peroxide was added to a final concentration of $30 \mathrm{~mm}$. A blue colour formation was visible after $5 \mathrm{~min}$, and was slightly increased during the following hour. The gels were then washed with a solution composed of 3 parts of isopropanol and 7 parts of $0.25 \mathrm{M}-\mathrm{Na}$ acetate, $\mathrm{pH} \mathrm{5}$, to remove excess TMBZ. The washing procedure was repeated once or twice after which the gels were photographed. A steelwire was inserted to mark the location of the haem stain.

Addition of solid sodium sulfite to the buffered isopropanol solution removed the peroxidase stained blue bands after approximately 2 hours. The gels were shaken during the destaining procedure. Prior to re-staining with $\mathrm{CoO}$ massie Brilliant Blue (Sigma Chem. Co.), the gels were washed several times with the buffered isopropanol solution. Coomassie Blue staining was conducted as earlier described (18).

\subsection{Labelling of haem and chlorophyll in thylakoids with $\left[{ }^{14} \mathrm{C}\right]-\delta$-aminolaevulinic acid}

Seedlings were grown for six days either in the dark or in the light (1700 lux). Excised leaves were placed in $10 \mathrm{ml}$ beakers $(10-14$ leaves per beaker) each of which contained $6 \mu \mathrm{Ci}$ of $\delta$ amino $\left[4-{ }^{14} \mathrm{C}\right]$ laevulinic acid hydrochloride $(0.1$ тм) (The Radiochemical Centre Amersham) in $1 \mathrm{ml} 25 \mathrm{~mm}$-sodium-phosphate, $\mathrm{pH}$ 7.5. After 4 hours, $2 \mathrm{ml}$ of distilled water was added to each beaker and the plants were left for an additional 16 hours prior to homogenization and purification of thylakoids.

\subsection{Fluorography of gels}

The localization of radioactive proteins in gels was determined by fluography. Gels were shaken in 2.5-diphenyloxazole (PPO) according to the procedure of BONNER and LASKEY (4) or in EN ${ }^{3} \mathrm{HANCE}^{\mathrm{TM}}$ (New England Nuclear) and stored in contact with Kodak X-omat RP X-ray film for appropriate time intervals at $-70^{\circ} \mathrm{C}$.

\section{RESULTS}

The TMBZ- $\mathrm{H}_{2} \mathrm{O}_{2}$ staining patterns obtained with barley thylakoid polypeptides separated on a $12-18 \%$ gradient gel (LiDS-PAGE) are shown in Figure 1A, lane 1. Two blue bands are observed, the apparent molecular weight of the upper one being 33,000 and that of the lower one approximately 20,000 . While the upper band is sharp, the lower band appears consistently broad and diffuse, indicating that the haem group is bound differently in the two cases or that the lower band comprises two or more polypeptides. The two green bands in lane 1 (Figure 1A) are chlorophyll $a$-protein 1 and chlorophyll $a / b$-protein 2 , respectively.

In lane 2 of Figure 1A, cytochrome $c$ was added prior to separation. The staining reaction produced a heavy band for this cytochrome at the appropriate molecular weight position. Heating of the solubilized thylakoids to $100^{\circ} \mathrm{C}$ prior to application to the gel removed the chlorophyll from the two chlorophyll-proteins (Figure IA, lane 3) but did not affect the binding of the haem in cytochrome $c$ and the other two haemproteins.

Figure 1B represents the same gel after restaining for protein with Coomassie Blue. The de- and re-staining procedures cause changes in the dimensions of the gels and the peroxidase positive bands were therefore marked with a steel-wire prior to de- and re-staining in order to locate the corresponding polypeptide bands. The upper sharp haem containing band corresponds to a faintly stained protein band while the lower diffuse band corresponds to two faint protein bands in the total pattern. Removal of chlorophyll led to the well known enhancement of the chlorophyll $a$-apoprotein band and the chlorophyll $a / b$-apoprotein 2 band. The strong colour reaction of cytochrome $c$ with TMBZ- $\mathrm{H}_{2} \mathrm{O}_{2}$ in Figure $1 \mathrm{~A}$ as compared to the faint staining observed with Coomassie Blue in Figure 1B illustrate the high sensitivity of the TMBZ- $\mathrm{H}_{2} \mathrm{O}_{2}$ staining method. 
G. Høyer-HANSEN: Barley thylakoid haem-proteins

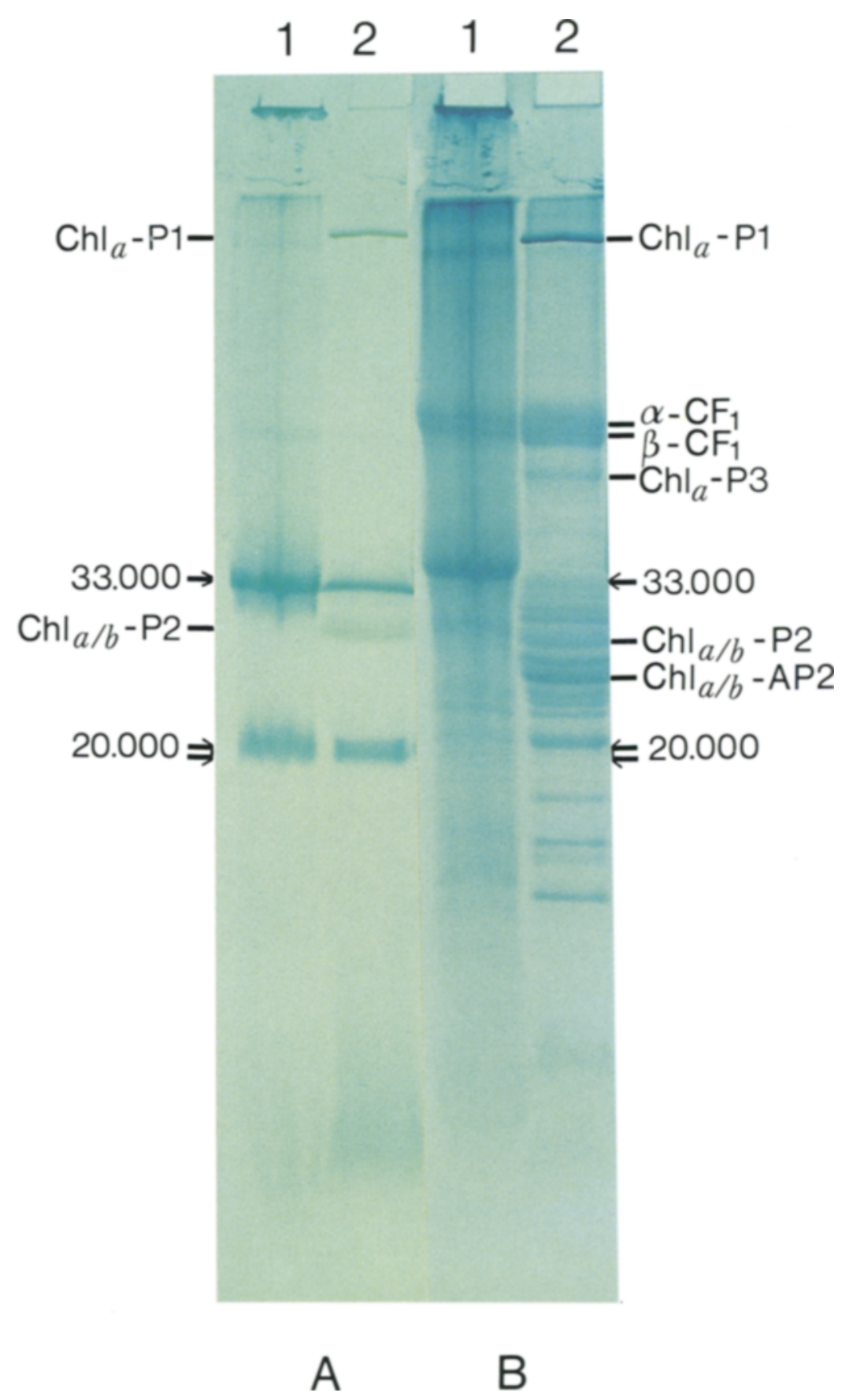

Figure 3. Etioplast and chloroplast thylakoid polypeptides separated by Li-dodecyl sulfate polyacrylamide gel electrophoresis and stained in A for haem associated peroxidase activity and restained in B for protein with Coomassie Blue.

Lane 1: Etioplast thylakoids

2: Chloroplast thylakoids 
Non-covalently bound haem as found for instance in the b-type cytochromes could conceivably dissociate from the protein during SDS solubilization under reducing conditions (20) and thereafter bind unspecifically to thylakoid polypeptides. In order to investigate to what extent thylakoid polypeptides bind haem unspecifically, barley thylakoids were mixed with 100 pmoles of hemin prior to SDS solubilization and electrophoresis. As can be seen in lanes 1 and 2 of Figure 2A a considerable number of thylakoid polypeptides now bind hemin. Comparison of a sample that had been heated to $100^{\circ} \mathrm{C}$ for $2 \mathrm{~min}$ (lane 1) with an unheated sample (lane 2) reveals that the conditions which remove chlorophyll from the polypeptides do not remove noncovalently bound hemin. Among the polypeptides binding hemin are $\mathrm{Chl}{ }_{\alpha}-\mathrm{P} 1, \alpha$ and $\beta$ subunits of $\mathrm{CF}_{1}, \mathrm{Chl}{ }_{a}$-AP3 and Chl $a / b-\mathrm{AP} 2$. Only a fraction of the 100 pmoles of hemin can bind to the thylakoid polypeptides as evidenced by the free hemin observed ahead of the free pigment zone. No DTT was included as reducing agent in this experiment, which makes the bands diffuse as is also apparent in the gel restained with Coomassie Blue (Figure 2B, lanes 1, 2). The two bands $(33,000 \mathrm{MW}, 20,000 \mathrm{MW})$ staining specifically with $\mathrm{TMBZ}-\mathrm{H}_{2} \mathrm{O}_{2}$ did not bind significant extra amounts of hemin. Hemin binding did also occur under reducing conditions.

When freshly isolated thylakoids were solubilized and analyzed by LiDS-PAGE additional faint bands were occasionally obtained. These faint bands corresponded to the $\alpha$ and $\beta$ subunits of $\mathrm{CF}_{1}$, to two bands in the vicinity of the 33,000 polypeptide and frequently to $\mathrm{Chl} a / b$-AP2. In these gels free haem was also seen in front of the free chlorophyll band. Thus detachment of noncovalently bound haem can occur and result in unspecific binding to other polypeptides.

In order to positively identify haem as the source of peroxidase activity in the bands with a molecular weight of 33,000 and 20,000 , the incorporation of $\left[{ }^{14} \mathrm{C}\right]-\delta$-aminolaevulinate, a precursor of chlorophyll and haem, was studied. Seedling leaves were detached and incubated for 2 hours with $\left[{ }^{14} \mathrm{C}\right]-\delta$-aminolaevulinate in the light as described under 2.4. The thylakoids were isolated, solubilized and separated on a 11-15\%
SDS gel. TMBZ- $\mathrm{H}_{2} \mathrm{O}_{2}$ staining in Figure 2A lane 3 reveals the two prominent bands with peroxidase activity. After de- and re-staining with Coomassie Blue this lane is depicted in Figure 2B, lane 3. An autoradiogram of the same lane is also shown (Figure 2C, lane 3 ) and indicates the incorporation of the precursor into the chlorophyll of $\mathrm{Chl}{ }_{a}-\mathrm{P} 1, \mathrm{Chl}{ }_{a} / b-\mathrm{P} 2$ and into the free chlorophyll band. Incorporation is also found in the 33,000 and $20,000 \mathrm{MW}$ bands, identifying the source of peroxidase activity in these bands as haem.

When the sample is heated prior to application on the gel (Figure 2A, B and C, lane 4), Chl ${ }_{a}-\mathrm{Pl}$ and the $\mathrm{Chl} a / b-\mathrm{P} 2$ disappears as does the radioactivity in these bands.

Synthesis of chlorophyll and chlorophyllproteins requires light, whereas haem and cytochromes are also formed in the dark. Thylakoids isolated from seven day old seedlings grown either in the dark or in the light, were therefore solubilized, subjected to LiDS-PAGE, and stained with $\mathrm{TMBZ}-\mathrm{H}_{2} \mathrm{O}_{2}$ (Figure $3 \mathrm{~A}$ ) as well as Coomassie Blue (Figure 3B). The TMBZ$\mathrm{H}_{2} \mathrm{O}_{2}$ positive haem containing bands $(33,000$ $\mathrm{MW}, 20,000 \mathrm{MW}$ ) are found in both etioplast and chloroplast thylakoids, whereas chlorophyllproteins are only present in the latter.

\section{DISCUSSION}

The TMBZ- $\mathrm{H}_{2} \mathrm{O}_{2}$ staining procedure (32) is suitable to localize haem in polyacrylamide gel patterns of barley thylakoid membrane polypeptides solubilized with either SDS of LiDS. In thylakoids, four haem-proteins have been described: cytochrome $f(2,3,11,22,23,26,29$, $31)$, cytochrome $b_{6}(6,12,27,28,29,30)$ cytochrome $b-559_{\mathrm{LP}}(1,23)$ and cytochrome $b-559_{\mathrm{HP}}(2,9,10,13,29,30)$. Cytochrome $f$ has been purified to homogeneity from several higher plants $(11,22,26,29,31)$, and its molecular weight varies from 27,000 to 39,000 . J. Gray (personal communication) obtained an apparent molecular weight of about 35,500 for partially purified barley cytochrome $f$. The observed TMBZ- $\mathrm{H}_{2} \mathrm{O}_{2}$ positive band with an apparent molecular weight of 33,000 thus fits the characteristics of cytochrome $f$. It should be 
mentioned that the haem in cytochrome $f$ is covalently bound.

Cytochrome $b_{6}$ has been purified from spinach (28). Its molecular weight is estimated to 60,000 and the molecule consists of four polypeptide chains with molecular weights of $20,000,9,600,6,600$ and 6,600 (28). The haem in cytochrome $b_{6}$ is non-covalently bound. If the haem is associated with the 20,000 molecular weight polypeptide, then the TMBZ- $\mathrm{H}_{2} \mathrm{O}_{2}$ positive band with this apparent molecular weight in the barley polypeptide pattern is a good candidate as a cytochrome $b_{6}$ subunit. Both cytochrome $f$ and cytochrome $b_{6}$ are present in etioplasts as judged by absorption spectroscopy $(3,23)$ and this is in agreement with the presence of the two haem staining polypeptides among the etioplast membrane polypeptides.

Cytochrome $b-559_{\mathrm{LP}}$ is present in etioplasts as well as chloroplasts whereas cytochrome $b-559_{\mathrm{HP}}$ is restricted to greening and greened plastids $(3,13,23)$. Cytochrome $b-559$ is considered to consist of eight polypeptide chains with a molecular weight of 5,600 per haem molecule (10). This polypeptide would be expected to produce a diffuse band below the region of cytochrome $c$ in the present electrophoretograms. No such band was detected.

In the analysis of cytochrome $P-450$ from liver microsomes by gel electrophoresis and TMBZ- $\mathrm{H}_{2} \mathrm{O}_{2}$ staining it was found that the use of sulfhydryl reducing agents together with SDS promoted the loss of haem from the haemprotein $(16,32)$. The thylakoids studied here were stored in $0.1 \mathrm{M}$-DTT, but no detrimental effects were found on the peroxidase activity of the 20,000 molecular weight haem-protein in comparison with conditions not using DTT. In that respect the presumed cytochrome $b_{6}$ subunit of the barley thylakoids is different from the microsomal cytochrome $P-450$.

\section{ACKNOWLEDGEMENTS}

I gratefully thank Dr. BIRGER LINDBERG MøLLER for stimulating discussions and Professor D. VON WETTSTEIN for critically reviewing the manuscript. Susanne Placing, Ann-Sofi Steinholtz, Nina Rasmussen, Hanne Them Nielsen and LENA KONGSRUd are thanked for skilful technical assistance. Financial support was pro- vided by EEC Contract 029-76-ES-DK Solar Energy Programme to Professor D. von WeTtSTEIN.

\section{REFERENCES}

1. Anderson, J. M. \& N. K. Boardman: Localization of low potential cytochrome $b-559$ in photosystem I. Febs Lett. 32, 157-160 (1973)

2. Boardman,N. K. \& J. M. Anderson: Fractionation of the photochemical systems of photosynthesis II. Cytochrome and carotenoid contents of particles isolated from spinach chloroplasts. Biochim. Biophys. Acta 143, 187-203 (1967)

3. Boardman, N. K.: Cytochromes of developing and mutant chloroplasts. In: Comparative Biochemistry and Biophysics of Photosynthesis, eds. K. Skibata, A. Takamiya, A. T. Jagendorf \& R. C. Fuller, University of Tokyo Press, pp. 206213 (1968)

4. BonNer, W. M. \& R. A. LASKey: A film detection method for tritium-labeled proteins and nucleic acids in polyacrylamide gels. Eur. $\mathbf{J}$. Biochem. 46, 83-88 (1974)

5. Chua, N.-H. \& P. Bennoun: Thylakoid membrane polypeptides of Chlamydomonas reinhardtii: Wild-type and mutant strains deficient in photosystem II reaction center. Proc. Nat. Acad. Sci. USA 72, 2175-2179 (1975)

6. Cox, R. P.: Composition and spectral properties of a cytochrome-enriched fraction obtained from chloroplasts by digitonin treatment. Biochem. J. 182, 613-615 (1979)

7. Delepelaire, P. \& N.-H. Chua: Lithium dodecyl sulfate/polyacrylamide gel electrophoresis of thylakoid membranes at $4^{\circ} \mathrm{C}$ : Characterisations of two additional chlorophyll a-protein complexes. Proc. Nat. Acad. Sci. USA 76, 111-115 (1979)

8. Gabriel, O.: Locating enzymes on gels. In: Metods Enzymol., ed. W. B. Jakoby, Academic press, New York and London 22, 578-605 (1971)

9. Garewal, H. S. \& A. R. Wasserman: Triton $\mathrm{X}-100-4 \mathrm{M}$-urea as an extraction medium for membrane proteins. I. Purification of chloroplast cytochrome $b_{559}$. Biochemistry 13, 4063-4071 (1974)

10. Garewal, H. S. \& A. R. Wassermann: Triton $\mathrm{X}-100-4 \mathrm{M}$-urea as an extraction medium for membrane proteins. II. Molecular properties of pure cytochrome b559: A lipoprotein containing small polypeptide chains and a limited lipid composition. Biochemistry 13, 4072-4079 (1974) 
11. Gray, J. C.: Purification and properties of monomeric cytochrome $f$ from Charlock, Sinapis arvensis L. Eur. J. Biochem. 82, 133-141 (1978)

12. Heber, U., N. K. Botrdman \& J. M. Anderson: Cytochrome $b-563$ redox changes in intact $\mathrm{CO}_{2-}$ fixing spinach chloroplasts and in developing pea chloroplasts. Biochim. Biophys. Acta 423, 275292 (1976)

13. Henningsen, K. W. \& N. K. Boardman: Development of photochemical activity and the appearance of the high potential form of cytochrome $b-559$ in greening barley seedlings. Plant Physiol. 51, 1117-1126 (1973)

14. Høyer-Hansen, G. \& D. J. Simpson: Changes in the polypeptide composition of internal membranes of barley plastids during greening. Carlsberg Res. Commun. 42, 379-389 (1977)

15. Høyer-Hansen, G., B. L. Møller \& L. C. Pan: Identification of coupling factor subunits in thylakoid polypeptide patterns of wild-type and mutant barley thylakoids using crossed immunoelectrophoresis. Carlsberg Res. Commun. 44, 337-351 (1979)

16. Levin; W., A. Y. H. Lu, D. Ryan, S. West, R. Kuntzman \& A. H. Conney: Partial purification and properties of cytochromes P-450 and P-448 from rat liver microsomes. Arch. Biochem. Biophys. 153, 543-553 (1972)

17. Machold, O. \& G. Høyer-Hansen: Polypeptide composition of thylakoids from viridis and xantha mutants in barley. Carlsberg Res. Commun. 41, 359-366 (1976)

18. Machold, O., A. Meister, H. Sagromsky, G. Hoyer-Hansen \& D. von Wettstein: Composition of photosynthetic membranes of wild-type barley and chlorophyll $b$-less mutants. Photosynthetica 11, 200-206 (1977)

19. Machold, O., D. J. Simpson \& B. L. Møller: Chlorophyll-proteins of thylakoids from wildtype and mutants of barley (Hordeum vulgare L.) Carlsberg Res. Commun. 44, 235-254 (1979)

20. Maines, M. D. \& M. W. Anders: Reconstitution of carbon monoxide-binding particles after removal of heme by serum albumin. Mol. Pharmacol. 9, 219-228 (1973)

21. Møller, B. L., R. M. Smillie \& G. Høyer-HanSEN: A photosystem I mutant in barley (Hordeum vulgare L.) Carlsberg Res. Commun. 45, 87-99 (1980)

22. Nelson, N. \& E. Racker: Partial resolution of the enzymes catalyzing photophosporylation. $\mathrm{X}$. Purification of spinach cytochrome $f$ and its photooxidation by resolved photosystem I particles. J. Biol. Chem. 247, 3848-3853 (1972)

23. Plesnicar, M. \& D. S. Bendall: The development of photochemical activities during greening of etiolated barley. In: Proc. 2nd Int. Congr. Photosynthesis. G. Forti, M. Avron \& B. A. Melandri, eds. Junk, The Hague pp. 2367-2374 (1972)

24. Simpson, D., G. Høyer-Hansen, N.-H. Chua \& D. vON WETTSTEIN: The use of gene mutants in barley to correlate thylakoid polypeptide composition with the structure of the photosynthetic membrane. Proc. Int. Congr. Photosynth., 4th, D. O. Hall, J. Coombs \& T. W. Goodwin, eds., Biochemical Society, England pp. 537-548 (1977)

25. Simpson, D., B. L. Møller \& G. Høyer-HanSEN: Freeze-fracture structure and polypeptide composition of thylakoids of wild-type and mutant barley plastids. In: Chloroplast development, G. Akoyunoglou \& J. H. ArgyroudiAkoyunoglou, eds., Elsevier/North-Holland, Biomedical Press, Amsterdam, pp. 507-512 (1978)

26. Singh, J. \& A. R. W Asserman: The use of disc gel electrophoresis with nonionic detergent in the purification of cytochrome $f$ from spinach grana membranes. J. Biol. Chem. 246, 3532-3541 (1971)

27. Stuart, A. L. \& A. R. Wasserman: Purification of cytochrome $b_{6}$ a tightly bound protein in chloroplast membranes. Biochim. Biophys. Acta 314, 284-297 (1973)

28. Stuart, A. L.: Studies on membrane proteins: Purification and molecular composition of cytochrome $b_{6}$ from spinach chloroplast membranes. PH.D. thesis (1974), McGill University, Canada.

29. Süss, K.-H.: Identification of chloroplast thylakoid membrane polypeptides: Coupling factor of photophosphorylation $\left(\mathrm{CF}_{1}\right)$ and cytochrome $f$. Febs. Lett. 70, 191-196 (1976)

30. Süss, K.-H.: Identification of chloroplast thylakoid membrane polypeptides. ATPase complex $\left(\mathrm{CF}_{1}-\mathrm{CF}_{0}\right)$ and light-harvesting chlorophyll a/ $b$-protein (LHCP) complex. Febs. Lett. 112, 255-259 (1980)

31. Tanaka, K., M. Takahashi \& K. Asada: Isolation of monomeric cytochrome $f$ from Japanese radish and a mechanism of autoreduction. J. Biol. Chem. 253, 7397-7403 (1978)

32. Thomas, P. E., D. Ryan \& W. Levin: An improved staining procedure for the detection of the peroxidase activity of cytochrome $P-450$ on 
G. HøYeR-HANSEN: Barley thylakoid haem-proteins

sodium dodecyl sulfate polyacrylamide gels. Anal. Biochem. 75, 168-176 (1976)

33. Wettstein, D. von, B. L. Møller, G. HøyerHANSEN \& D. Simpson: Mutants in the analysis of the photosynthetic membrane polypeptides. In: Origin of chloroplasts, J. A. Schiff \& R. Y. Stanier, eds., Elsevier/North-Holland, Biomedical Press, Amsterdam, in press (1980) 